\title{
Pinnularia aljustrelica sp. nov. (Bacillariophyceae), a new diatom species found in acidic waters in the Aljustrel mining area (Portugal) and further observations on the taxonomy and ecology of $P$. acidophila Hofmann et Krammer and $P$. acoricola HuSTEDT
}

\author{
Ana T. Luís ${ }^{1,2,3}$, Maria Helena Novais 3 , Bart VAn De ViJver ${ }^{4}$, Salomé F.P. Almeida ${ }^{2}$, \\ Eduardo A. Ferreira da Silva ${ }^{1}$, Lucien HofFMANN ${ }^{3} \&$ Luc Ector $^{3}$ \\ ${ }^{1}$ Universidade de Aveiro, Department of Geosciences, Geobiotec-Geobiosciences, Technologies and Engineering, \\ Campus de Santiago, P-3810-193 Aveiro, Portugal; corresponding author e-mail: anatluis@ua.pt \\ ${ }^{2}$ Universidade de Aveiro, Department of Biology, Geobiotec - Geobiosciences, Technologies and Engineering, \\ Campus de Santiago, P-3810-193 Aveiro, Portugal \\ ${ }^{3}$ Public Research Centre - Gabriel Lippmann, Department of Environment and Agro-Biotechnologies (EVA), 41 \\ rue du Brill, L-4422 Belvaux, Luxembourg \\ ${ }^{4}$ National Botanic Garden of Belgium, Department of Bryophyta and Thallophyta, Domein van Bouchout, B-1860 \\ Meise, Belgium
}

\begin{abstract}
A new benthic freshwater diatom species belonging to the genus Pinnularia EHRENB. has been recorded in the Água Forte stream surrounding the Aljustrel mining area in southern Portugal. Pinnularia aljustrelica Luís, Almeida et Ector sp. nov. is described as a new species based on light and scanning electron microscopy observations and on its particular habitat in an acidic environment due to acid mine drainage, high metal concentrations (As, $\mathrm{Cd}$, $\mathrm{Cu}, \mathrm{Fe}, \mathrm{Mn}, \mathrm{Pb}$ and $\mathrm{Zn}$ ) and high sulphate and conductivity.

The taxa most similar to P. aljustrelica are P. acidophila Hofmann et Krammer, P. acoricola Hustedt and $P$. acoricola var. lanceolata HusteDT, so type materials of these taxa were studied for comparative purposes. Although, the ecology of the three similar taxa is also quite similar, the new species has a combination of particular morphological characteristics studied under LM and SEM that separates it from the rest. Pinnularia aljustrelica has a general shape relatively similar to $P$. acidophila and P. acoricola, but the valve outline is not as linear as in $P$. acidophila and not as oval as in P. acoricola.
\end{abstract}

Key words: Pinnularia aljustrelica, new species, morphology, extreme acidic environment, Portugal

\section{Introduction}

The pyrite tailings of Aljustrel (Southern Portugal) are characterized by a total lack of vegetation and the nearby streams are strongly affected by acid mine drainage (AMD) produced when pyritic minerals are exposed to weathering, resulting in very low $\mathrm{pH}$ (formation of sulphuric acid), high conductivity, elevated sulphate content and high concentrations of dissolved metals as arsenic (As), cadmium $(\mathrm{Cd})$, copper $(\mathrm{Cu})$, iron $(\mathrm{Fe})$, manganese $(\mathrm{Mn})$, lead $(\mathrm{Pb})$ and zinc $(\mathrm{Zn})$ (Skousen et al. 1994). A new diatom species was found in this area during a survey in the 2008-2009 period. The new taxon resembled other species currently ascribed to Pinnularia, a genus commonly reported from similar highly acidic conditions. The acidic conditions increase bio-availability of metals (Luis et al. 2009), thus making the monitoring of the ecosystem through biological studies highly necessary.

Diatoms are one of the principal groups of organisms in these affected streams; making them excellent bio-indicators based on their high sensitivity to changes in environmental conditions (Bahls 1993; STEVEnson \& Pan 1999; BlinN \& Herbst 2003). Based on literature data (CARTER 1972; Whitton \& Diaz 1981; Negoro 1985; CASSIE \& CoOper 1989; Watanabe \& Asai 1995; Sabater et al. 2003), one of the most widespread taxa in acidic waters is apparently Pinnularia acoricola HustedT, described in 1935 in Java from sulphaterich waters with a $\mathrm{pH}$ of 2.4. Pinnularia acoricola var. lanceolata HUSTEDT was also discovered 
in Indonesia (Lake Toba, Sumatra), as a fossil freshwater diatom (HuSTEDT 1935). LESSMANN et al. (1999) recorded P. acoricola in an extreme acidic lake with high concentrations of calcium, iron, aluminium, manganese and sulphate. This taxon has a variable morphology resembling $P$. obscura KRASSKE (CARTER 1972). Both species, $P$. acoricola and $P$. obscura, were observed in waters with low $\mathrm{pH}$ in England (Hargreaves et al. 1975), North America (Whitton \& DiAz 1981) and South Africa (DeNicola 2000). Apparently, these diatoms seem to be well adapted to low $\mathrm{pH}$ conditions allowing them to develop large communities in otherwise inhospitable environmental conditions. The morphology of $P$. acoricola is clearly influenced by the ecological conditions resulting in a high variety of sizes and shapes, e.g. P. acoricola var. osoresanensis Negoro described in Japan by Negoro (1944), then transferred at the species level by FuKUSHIMA et al. (2002) as P. osoresanensis (Negoro) Fukushima, Yoshitake et Ko-BAYAshi. Recently, P. acidophila Hofmann et Krammer in Krammer (Krammer 2000) was described from Eastern Germany in a lake resulting from an opencast mining of low $\mathrm{pH}$.

The main purpose of the present work is to study the Pinnularia populations of the Aljustrel mining area in southern Portugal. For this purpose, the type materials of $P$. acidophila, $P$. acoricola and $P$. acoricola var. lanceolata were investigated in order to clarify the differences and similarities of these species with the Southern Portuguese Pinnularia. This detailed examination by means of light (LM) and scanning electron microscopy (SEM), as well as the particular environmental characteristics of the streams surrounding this mining area lead us to propose a new Pinnularia species, here described in detail.

\section{Material and Methods}

One litre of water was collected from the surface, as close to the centre of the stream as possible, in Ponte Monte Ruas and Porto de Beja sites (Aljustrel mining area - Southern Portugal, Fig. 1), simultaneously with the diatom sampling. Then, the surface water samples were returned in a cool box to the laboratory and stored at $4{ }^{\circ} \mathrm{C}$ before the analyses according to the protocols proposed by German Chemists Association (1981), EPA-Environmental Protection Agency (1982) and ASTM (1984). Temperature $\left(\mathrm{T},{ }^{\circ} \mathrm{C}\right), \mathrm{pH}$ and electrical conductivity (EC, $\mu \mathrm{S} . \mathrm{cm}^{-1}$, at $25{ }^{\circ} \mathrm{C}$ ) were measured directly in the field with a WTW ${ }^{\circledR}$ Multiline P4 set.

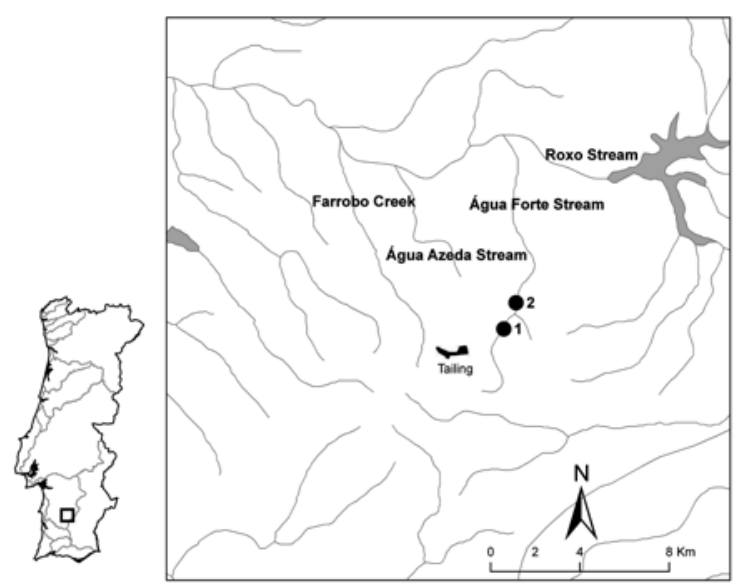

Fig. 1. Sampling sites where Pinnularia aljustrelica was found (Água Forte stream near the Aljustrel tailing): (1) Ponte Monte Ruas; (2) Porto de Beja.

The determination of $\mathrm{As}, \mathrm{Ca}, \mathrm{Cd}, \mathrm{Cl}, \mathrm{Cu}, \mathrm{Fe}, \mathrm{K}, \mathrm{Mg}$, $\mathrm{Mn}, \mathrm{Na}, \mathrm{Pb}$, and $\mathrm{Zn}$ was carried out using ICP-MS. The determination of $\mathrm{COD}, \mathrm{NH}_{4}^{+}$and $\mathrm{PO}_{4}^{3-}$ was done by spectrophotometry. For $\mathrm{NO}_{3}^{-}$and $\mathrm{SO}_{4}{ }^{2-}$ determination, ion chromatography was used (all the concentrations of the chemical elements were expressed in mg. $\mathrm{l}^{-1}$ ).

Epipsammic diatoms were collected from the sediment with a syringe, four times at Ponte Monte Ruas (site $1-37^{\circ} 52^{\prime} 22.87^{\prime \prime} \mathrm{N} ; 8^{\circ} 8^{\prime} 59.42^{\prime \prime} \mathrm{W}$ ), twice in 2008 (spring and summer) and twice in 2009 (spring and winter). Porto de Beja (site $2-37^{\circ} 53^{\prime} 0.69^{\prime \prime} \mathrm{N}$; $8^{\circ} 8^{\prime} 36.83^{\prime \prime} \mathrm{W}$ ) was sampled only once, in spring 2008. Both sites are located in the Água Forte stream that surrounds the Aljustrel mining area.

Four samples from Hofmann's and Hustedt's type material collections were also examined for this study: - Material received from G. Hofmann (holotype material of Pinnularia acidophila HofMANN et KRAMMER, corresponding to the slide number 61B IOK in KRAMMER collection); Locality: Braunkohlerestsee, Lausitz, Restloch 107, 0-2 cm (lake resulting from an opencast mining, Lausitz, Eastern Germany); Collection date: 21/05/1996; Collector name: G. Hofmann.

- Material number AS403 (lectotype material of Pinnularia acoricola HustedT); Locality: Java, Dieng-Plateau, D3b, Telaga Pengilan, Schwingrasen; Substratum: Sphagnum; Collection date: 06/03/1929; Collector name: F. RutTNER; Friedrich-HustedtZentrum für Diatomeenforschung, Alfred-Wegener Institut für Polar und Meeresforschung, Bremerhaven (BRM).

- Material number AS895 (material with abundant Pinnularia acoricola HUSTEDT); Locality: Sumatra, Lake Toba, TW1d, W-Ufer Samosir, N-Sigaol; Substratum: mud; Collection date: 04/11/1929; Collector name: F. RUTTNER; Friedrich-HustedtZentrum für Diatomeenforschung, Alfred-Wegener 
Institut für Polar und Meeresforschung, Bremerhaven (BRM).

- Material number AS956 (holotype material of Pinnularia acoricola var. lanceolata HuSTEDT); Locality: Sumatra, Lake Toba, TD4, fossil, West Coast of Samosir Island; Substratum: diatomite; Collection date: 01/01/1929; Collector name: F. RutTNER; Friedrich-Hustedt-Zentrum für Diatomeenforschung, Alfred-WegenerInstitut fürPolarund Meeresforschung, Bremerhaven (BRM).

The samples from Aljustrel mining area were treated in the laboratory with nitric acid $\left(\mathrm{HNO}_{3} 65 \%\right)$ and potassium dichromate $\left(\mathrm{K}_{2} \mathrm{Cr}_{2} \mathrm{O}_{7}\right)$ at room temperature for $24 \mathrm{~h}$, followed by three centrifugations (1500 $\mathrm{rpm})$ to wash the excess of acid, then treated with hydrochloric acid ( $\mathrm{HCl} \mathrm{37 \% )} \mathrm{during} \mathrm{more} \mathrm{than} 24 \mathrm{~h}$ to disaggregate the valves, and then cleaned again, through three centrifugation cycles $(1500 \mathrm{rpm})$ to wash the excess of $\mathrm{HCl}$. The samples from Hofmann's and Hustedt's collections were rinsed out of fixatives, treated by oxidation with hot hydrogen peroxide $\left(\mathrm{H}_{2} \mathrm{O}_{2}\right.$ 120 vols.) and hydrochloric acid, and then rinsed three times with deionised water in order to obtain a suspension of clean frustules. Permanent slides were mounted using the high refractive index (1.74) medium Naphrax ${ }^{\circledR}$ (Brunel Microscopes Ltd, UK). Light microscopy observations were taken using a Leica ${ }^{\circledR}$ DMRX light microscope (DIC contrast) with a 100 $\mathrm{x}$ oil immersion objective and LM photographs were taken with a Leica ${ }^{\circledR}$ DC500 camera. Samples chosen for scanning electron microscopy were filtered through polycarbonate membrane filters with a $3 \mu \mathrm{m}$ pore diameter, mounted on stubs with double sided carbon tape, sputtered with platinum $(30 \mathrm{~nm})$ with a Modular High Vacuum Coating System (BAL-TEC MED 020) and studied with a HITACHI SU-70, operated at $5.0 \mathrm{kV}$. Morphometric parameters were obtained from LM and SEM photographs: a total of 162 valves (110 of Pinnularia aljustrelica sp. nov., 23 of $P$. acidophila, 28 of $P$. acoricola and 1 of $P$. acoricola var. lanceolata type materials) were measured.

Morphological terminology follows RounD et al. (1990) and Krammer (2000). Apart from the original descriptions of $P$. acidophila, $P$. acoricola and $P$. acoricola var. lanceolata, the following publications were consulted for taxonomical and ecological comparison (Table 1): Hustedt in SchMidT et al. (1934), Hustedt (1935), Negoro (1944), CARter (1972), SimONSEN (1987), Krammer (2000), Jordan (2001), Wydrzycka \& Lange-Bertalot (2001), Fukushima et al. (2002), VAn DE ViJVer et al. (2002) and Metzeltin et al. (2005).

Bibliographical references of similar taxa with illustrations, which made the comparison possible with our populations, were also used e.g., Negoro (1985), Watanabe \& Asai (1995), Idei \& Mayama (2001), JoRDAN (2001) and HobBs et al. (2009).
All images were digitally manipulated and plates made using Microsoft Photo Editor 3.01, Microsoft PowerPoint 2000 SP-3 and Adobe Photoshop Elements v. 2.0.

The map of the sites where the new Pinnularia species (Fig. 1) was found was generated using GIS software ARCGIS 9.3 (ESRI 2008).

\section{Results and Discussion}

\section{Pinnularia aljustrelica Luís, Almeida et Ector sp. nov.}

Figs 2-21: LM, Figs 157-161: SEM

Diagnosis: Valvae anguste lanceolatae ad rhombicaelanceolatae apicibus non protractis, late rotundatis.

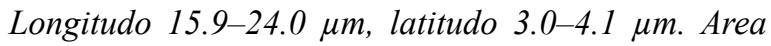
axialis angusta, linearis. Area centralis rhombica formans fasciam leviter ad moderate latam, rotundam. Raphe recta poris proximalibus unilateraliter deflexis. Fissurae terminales raphis curvatae ad idem latus valvae. Striae transapicales fortiter radiatae in media parte valvae, abrupte valde convergentes ad apices, 15-18 in $10 \mu \mathrm{m}$.

Holotype (here designated): slide BR-4230 (National Botanic Garden, Meise, Belgium).

Isotype (here designated): slide BRM-ZU8/11 (Friedrich Hustedt Diatom Collection, Alfred Wegener Institute for Polar and Marine Research, Bremerhaven, Germany).

Type locality: Ponte Monte Ruas, Água Forte stream (Ribeira da Água Forte), municipality of Aljustrel, subregion of Baixo Alentejo (District: Beja), Portugal; collector: Ana T. Luís; collection date: 07/04/2008; geographical coordinates: 4192136.37 N, (29)574774.42 W; Etymology: The specific epithet aljustrelica refers to the name of the type locality.

\section{Light microscopy (Figs 2-21)}

Valves narrowly lanceolate to rhombic-lanceolate, gradually tapering towards the broadly rounded, non protracted apices. Valve dimensions of the type population $(\mathrm{n}=19)$ : length $15.9-24.0 \mu \mathrm{m}$, width 3.0-4.1 $\mu \mathrm{m}$ (Table 2). Axial area narrow, linear. Central area rhomboid forming a small to moderately large, rounded fascia. Raphe straight with unilaterally deflected proximal raphe endings. Transapical striae strongly radiate near the valve centre, changing abruptly to convergent towards the apices, $15-18$ in $10 \mu \mathrm{m}$. 


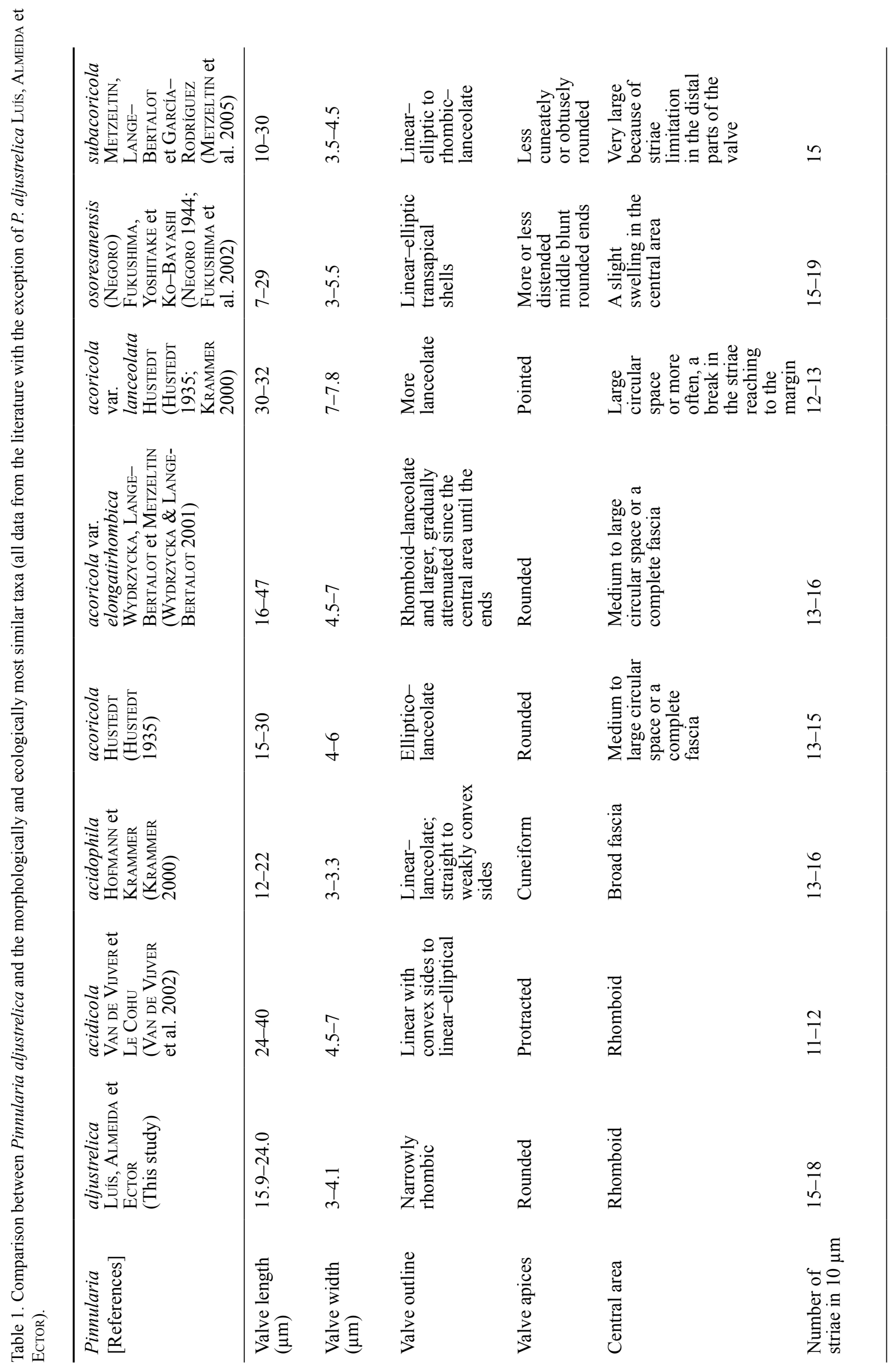




\begin{tabular}{|c|c|c|}
\hline 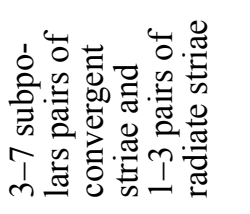 & 泀 & 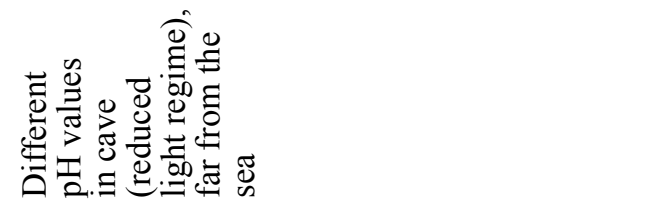 \\
\hline 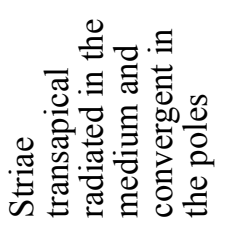 & 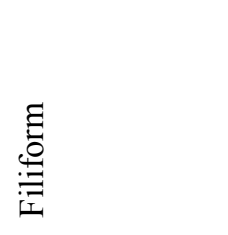 & 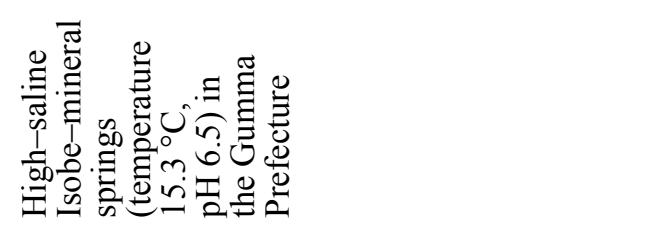 \\
\hline 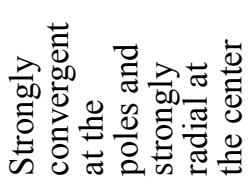 & 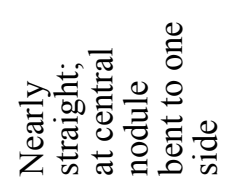 & 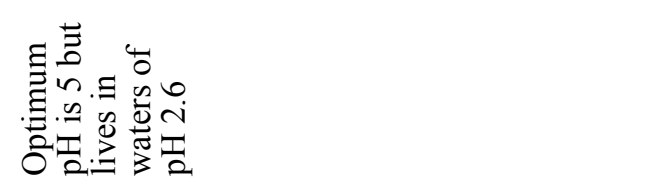 \\
\hline 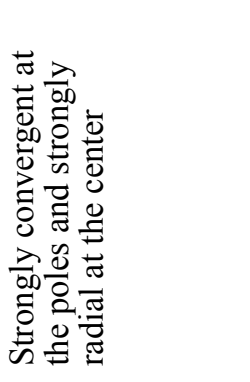 & 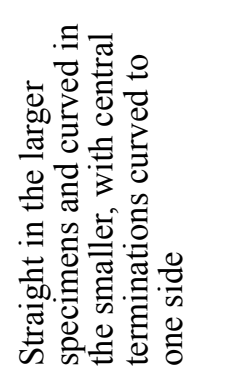 & 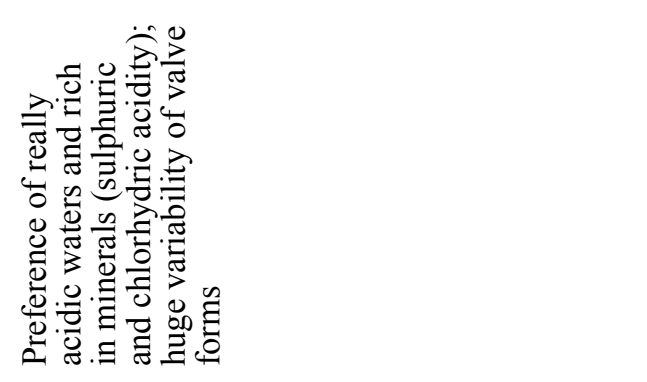 \\
\hline 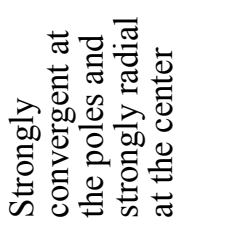 & 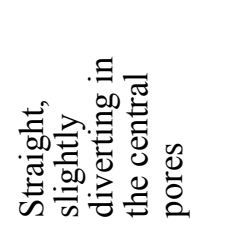 & 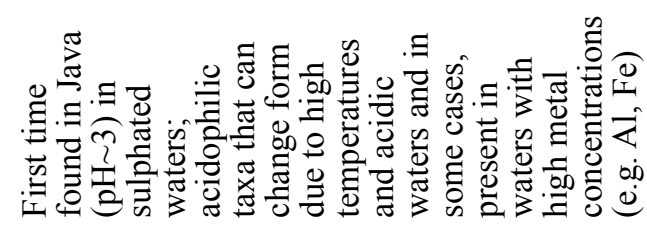 \\
\hline 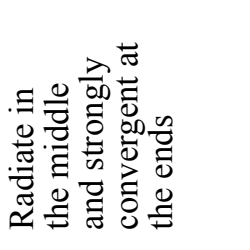 & 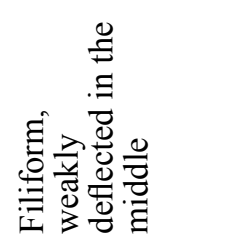 & 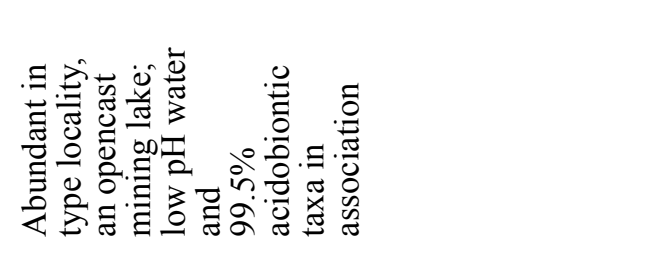 \\
\hline 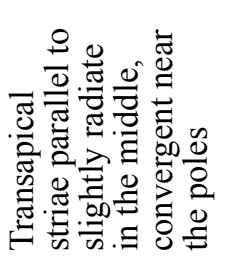 & 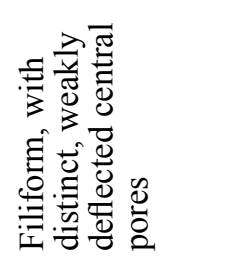 & 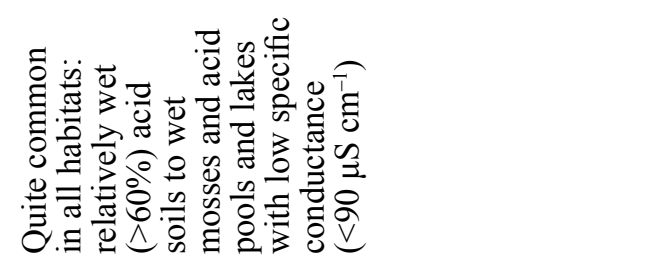 \\
\hline 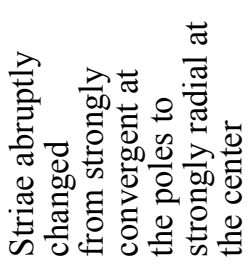 & 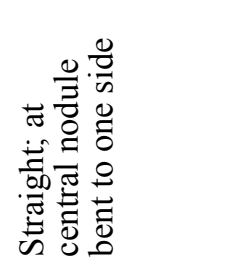 & 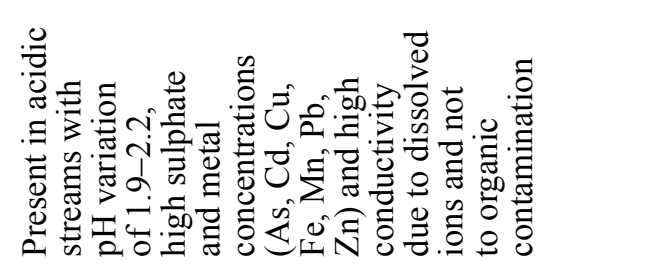 \\
\hline 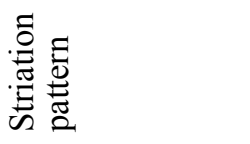 & 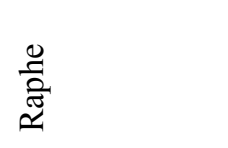 & 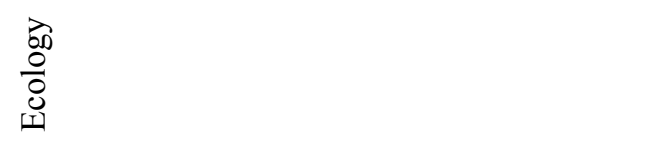 \\
\hline
\end{tabular}



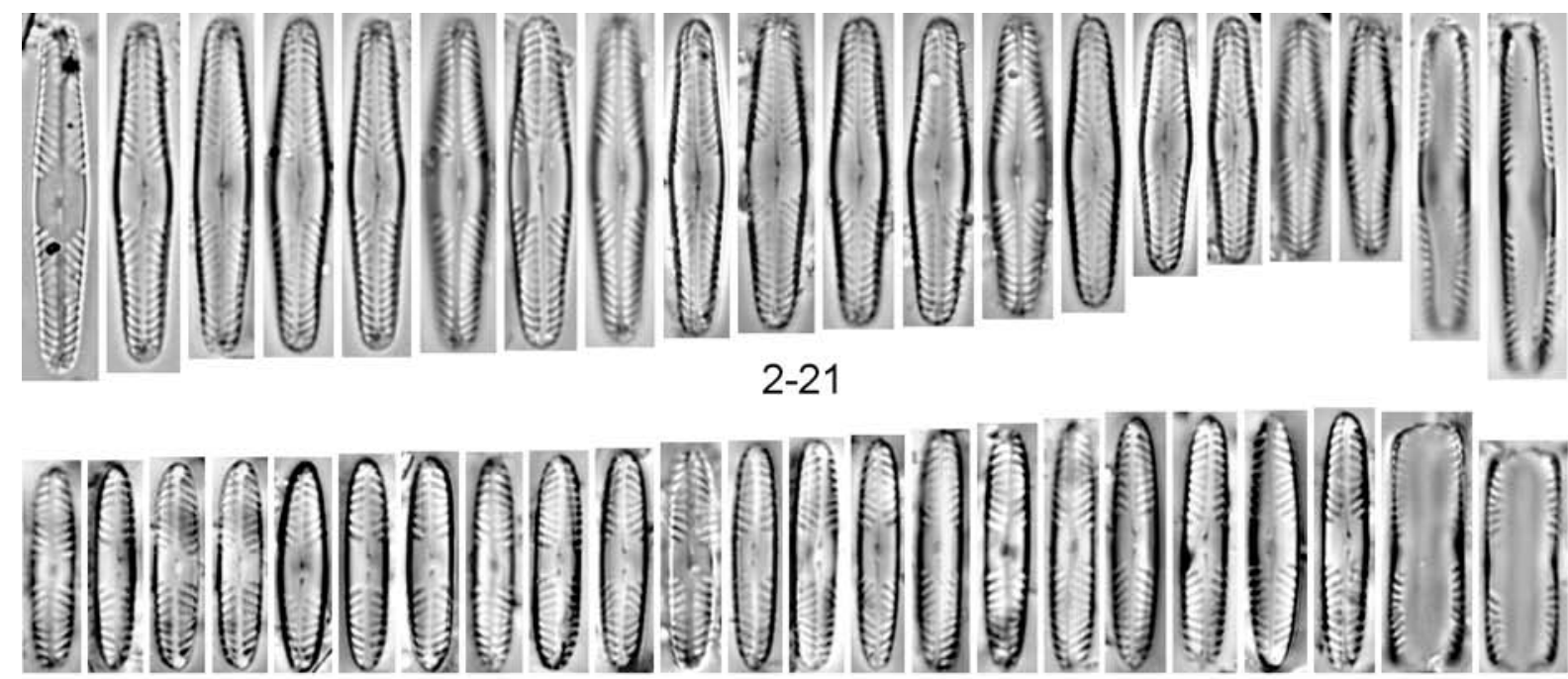

$22-44$
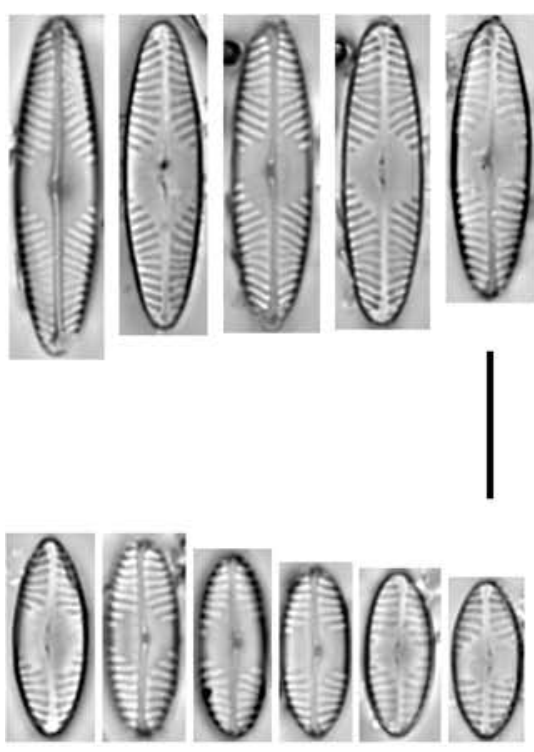

$60-65$

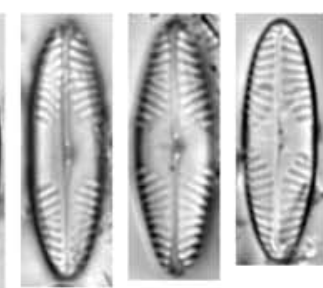

$45-59$
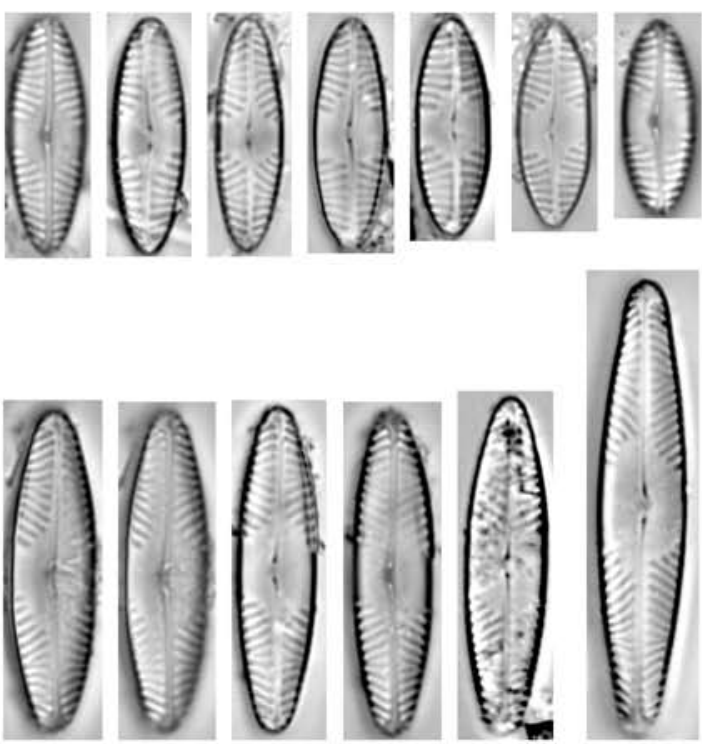

74

Figs 2-21. Pinnularia aljustrelica sp. nov. Luis, AlmEIDA et Ector. Light micrographs of the type population sampled in Ponte Monte Ruas in spring 2008, Água Forte stream (Aljustrel, Portugal): (2-19) valvar view; (20-21) girdle view.

Figs 22-44. Pinnularia acidophila Hofmann et Krammer. Light micrographs of the type population: (22-42) valvar view; (43-44) girdle view. Figs 45-65. Pinnularia acoricola HustedT. Light micrographs of the type population in valvar view.

Figs 66-73. Pinnularia acoricola HustedT. Light micrographs, in valvar view (found in the type material of Pinnularia acoricola var. lanceolata HUSTEDT)

Fig. 74. Pinnularia acoricola var. lanceolata HustedT. Light micrograph, in valvar view (holotype material). Scale bar 10 $\mu \mathrm{m}$.

\section{Scanning electron microscopy (Figs 157-161)}

Proximal raphe endings weakly expanded, never drop-like (Fig. 159). The terminal raphe endings are curved towards the secondary side of the valves while the central pores are deflected to the primary side of the valve (Fig. 157). Each alveolus composed of 3-5 rows of very small, rounded pores, usually externally covered by a membrane (Figs 160, 161). Internally, the raphe fissure shows no intermission near the central nodule (Fig. 160) and the distal raphe endings terminate on small helictoglossae (Fig. 161).

\section{Morphometric variability}

The type population of Pinnularia aljustrelica shows a length range between 15.9 and $24.0 \mu \mathrm{m}$, a width of 3.0 to $4.1 \mu \mathrm{m}$ and a stria density of $15-18$ in $10 \mu \mathrm{m}$. The other three populations observed at 


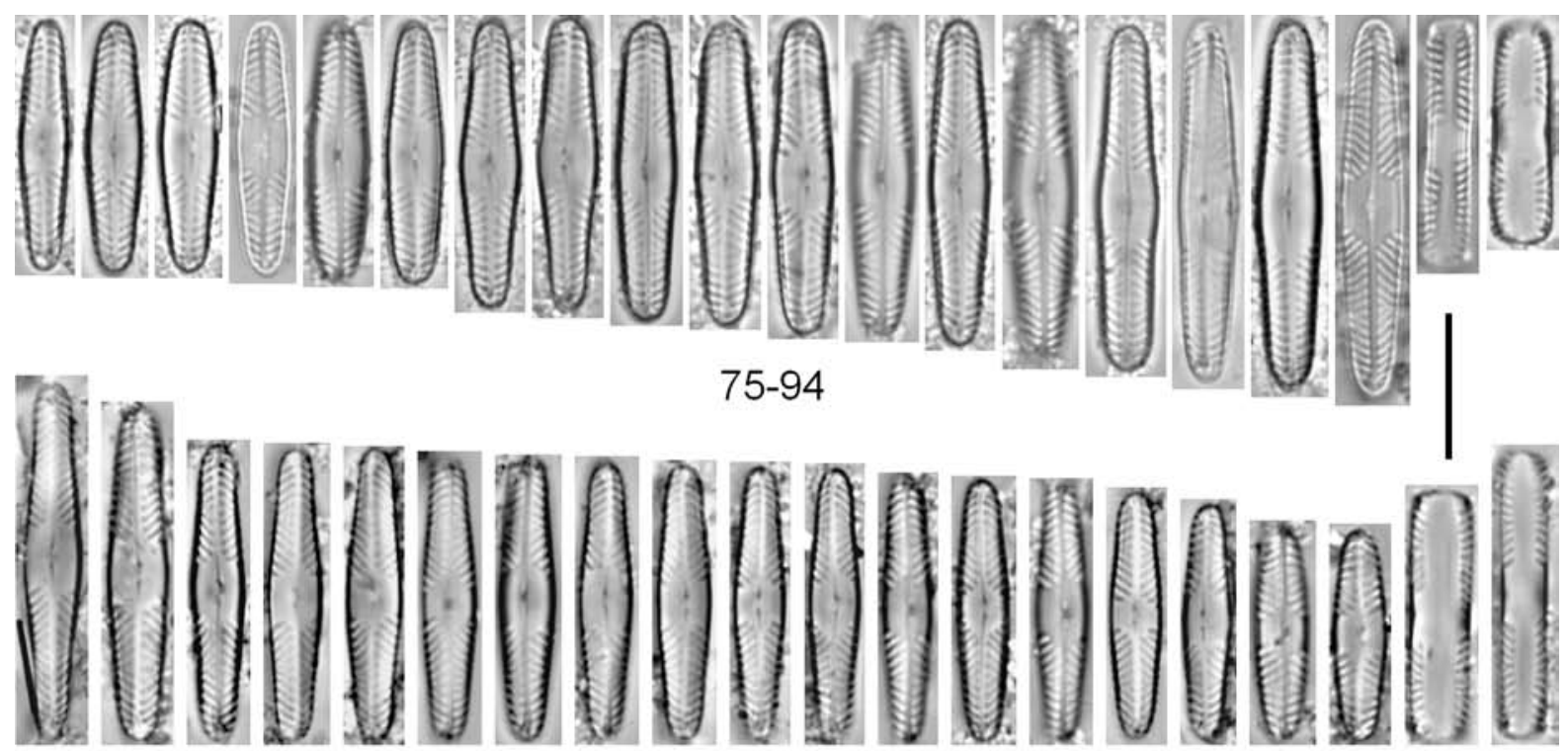

$95-114$

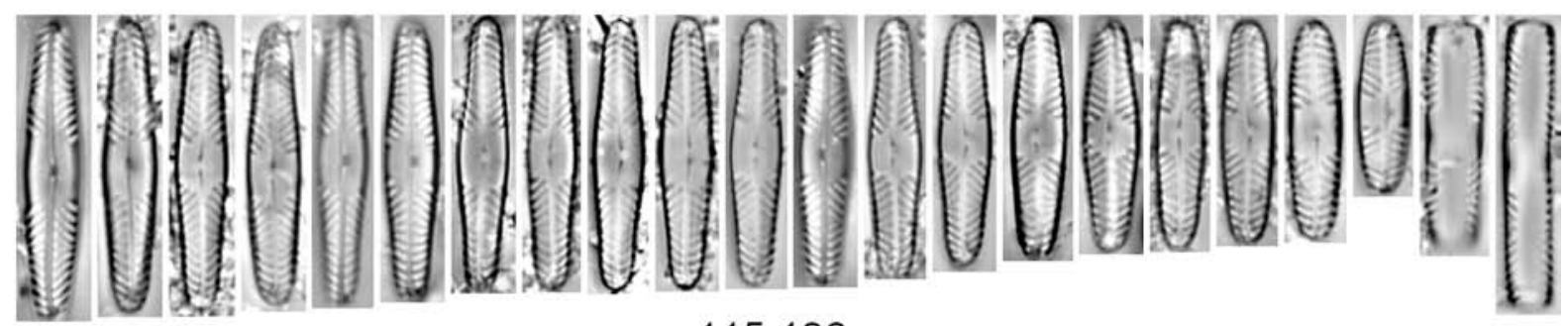

$115-136$

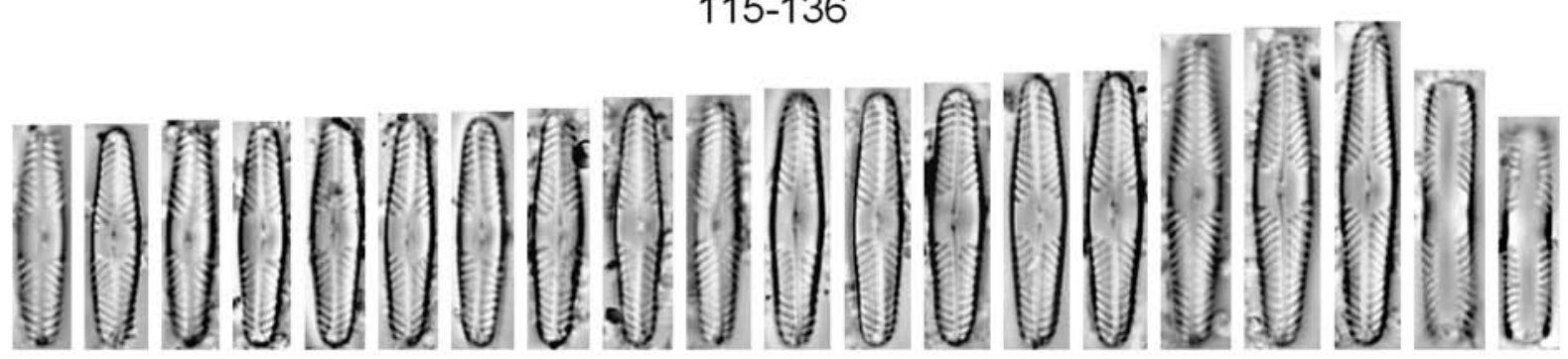

137-156

Figs 75-156. Pinnularia aljustrelica sp. nov. Luís, AlmEIDA et Ector: Figs 75-94. Light micrographs of the population sampled in Ponte Monte Ruas in summer 2008, Água Forte stream (Aljustrel, Portugal): (75-92) valvar view; (93-94) girdle view. Figs 95-114. Light micrographs of the population sampled in Ponte Monte Ruas in spring 2009, Água Forte stream (Aljustrel, Portugal): (95-112) valvar view; (113-114) girdle view. Figs 115-136. Light micrographs of the population sampled in Ponte Monte Ruas in winter 2009, Água Forte stream (Aljustrel, Portugal): (115-133) valvar view; (135-136) girdle view. Figs 137156. Light micrographs of the population sampled in Porto de Beja in spring 2008, Água Forte stream (Aljustrel, Portugal): (137-154) valvar view; (155-156) girdle view. Scale bar $10 \mu \mathrm{m}$.

Ponte Monte Ruas presented a slightly different range in valve dimensions (Table 2). During the summer of 2008 (Figs 75-94), valves showed a length ranging from 11.3 to $25.7 \mu \mathrm{m}$, a width of 3.0 to $3.9 \mu \mathrm{m}$ and a stria density of $14-17$ in $10 \mu \mathrm{m}$. In spring 2009 (Figs 95-114) the valve length varied between $14.3-24.3 \mu \mathrm{m}$ with a width of 3.0-3.8 $\mu \mathrm{m}$ and $16-18$ striae in $10 \mu \mathrm{m}$. Finally, in the sample taken in winter 2009 (Figs 115-136,
173-177), the observed length varied between $11.5-20.0 \mu \mathrm{m}$, while the width ranged between 3.1-3.7 $\mu \mathrm{m}$ and the striae were $15-18$ in $10 \mu \mathrm{m}$. The Porto de Beja population (Figs 137-156) had a range in length of 14.5 to $21.7 \mu \mathrm{m}$, width of 3.0 to $3.8 \mu \mathrm{m}$ and $16-18$ striae in $10 \mu \mathrm{m}$. A total of 110 valves were measured for all populations (length of 11.3 to $25.7 \mu \mathrm{m}$, width of 3.0 to $4.1 \mu \mathrm{m}$, stria density of $14-18$ in $10 \mu \mathrm{m})$. 

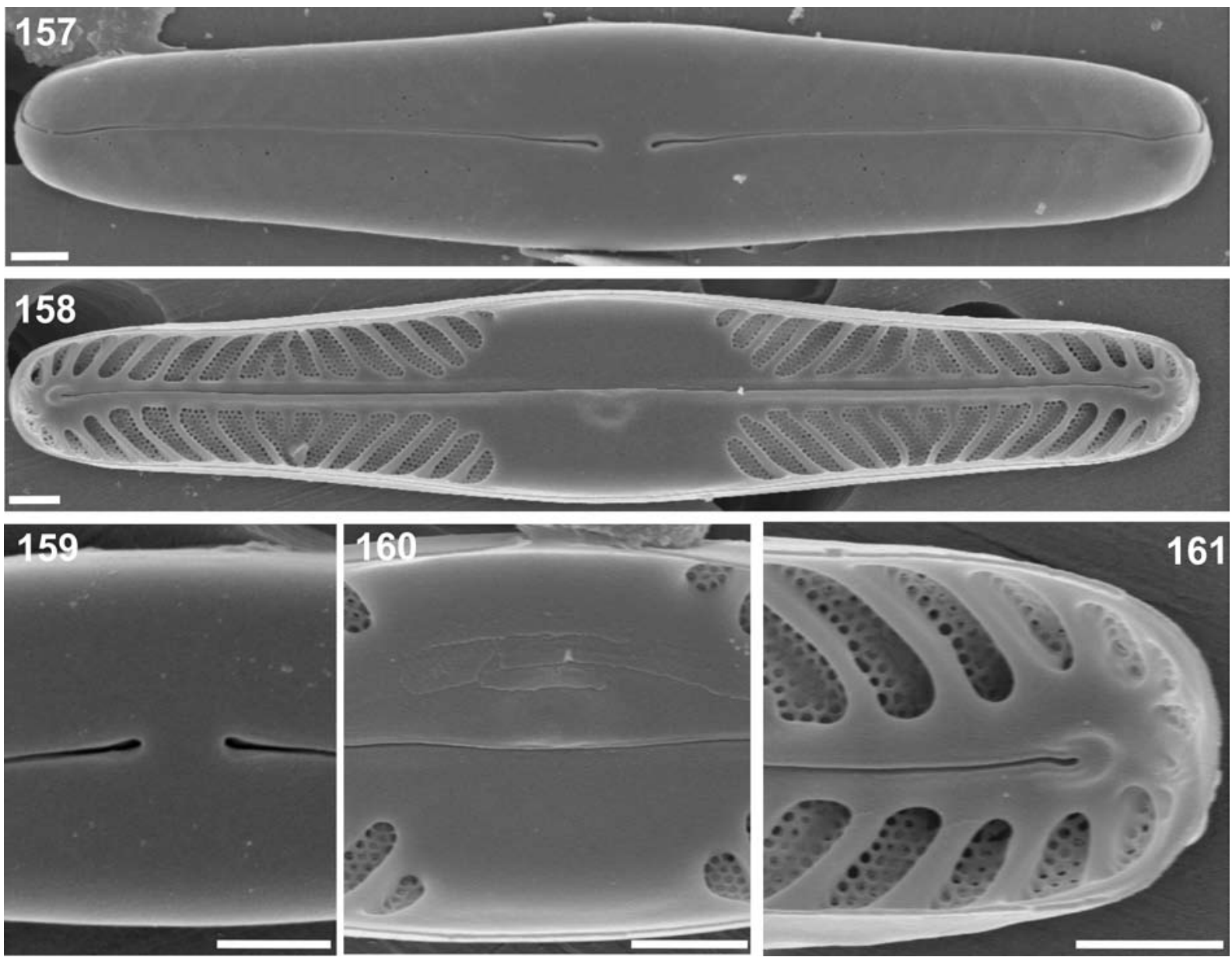

Figs 157-161. Pinnularia aljustrelica sp. nov. Luís, ALMEIDA et ECTOR. Scanning electron micrographs of the type population sampled in Ponte Monte Ruas in spring 2008, Água Forte stream (Aljustrel, Portugal): (157) external valve view: terminal fissure curved in the same direction and the terminal raphe endings deflected to the primary side; (158) internal valve view; (159) external view of the raphe with the proximal endings weakly expanded; (160) internally, the raphe fissure shows no intermission near the central nodule; (161) internal view of the apex, showing the distal raphe endings terminating on small helictoglossae, the areolae features of the striae and the structure of the alveoli. Scale bars $1 \mu \mathrm{m}$.

\section{Ecology, distribution and associated diatom flora}

The ecological preferences of the new Pinnularia species were inferred based on environmental variables from two sites of the Água Forte stream in the Aljustrel mining area (Portugal). Pinnularia aljustrelica dominates the investigated stream Água Forte. Table 3 shows all environmental parameters. Both sites have highly acidic waters with a rather constant low $\mathrm{pH}$ (1.9-2.3), high sulphate levels (16995-36900 mg.1 $\left.\mathrm{l}^{-1} \mathrm{SO}_{4}^{2-}\right)$, high metal concentrations (As: $1.90-52.17 \mathrm{mg} . \mathrm{l}^{-1} ; \mathrm{Cd}$ : 1.62-2.48 mg. $\mathrm{l}^{-1}$; Cu: $130-348 \mathrm{mg} . \mathrm{l}^{-1}$; Fe: 3688 6173 mg. $1^{-1}$; Mn: 66-204 mg..$^{-1}$; Pb: $<0.01-1.20$ mg. $\left.1^{-1} ; \mathrm{Zn}: 766-1202 \mathrm{mg} . \mathrm{l}^{-1}\right)$ and high conductivity (12200-17140 $\left.\mu \mathrm{S} . \mathrm{cm}^{-1}\right)$ caused by dissolved ions in the water. The water temperature varied between $9.1-29.2{ }^{\circ} \mathrm{C}$. In total, P. aljustrelica was recorded in two sites of the Água Forte stream at five sampling moments with abundances above $91 \%$.

\section{Comparison with related taxa}

The most similar taxa to Pinnularia aljustrelica are P. acidophila and P. acoricola (Table 4).

The first taxon in this comparison is $P$. acidophila (Figs 22-44, 162-166). Our analysis of the type material of $P$. acidophila shows some differences in valve length (13.6-17.3 $\mu \mathrm{m})$, width $(2.5-3.1 \mu \mathrm{m})$ and number of striae in $10 \mu \mathrm{m}$ (15-18) compared with the original description of Krammer (2000): $12-22 \mu \mathrm{m}$ in length, $3.0-3.3$ in width, 13-16 striae in $10 \mu \mathrm{m}$. The main differences between $P$. acidophila and P. aljustrelica include a narrower valve width and a more linear to lanceolate valve outline lacking the larger width in the central area (Figs 22-42) instead of lanceolate to rhombic shape in P. aljustrelica (Figs 2-19). 

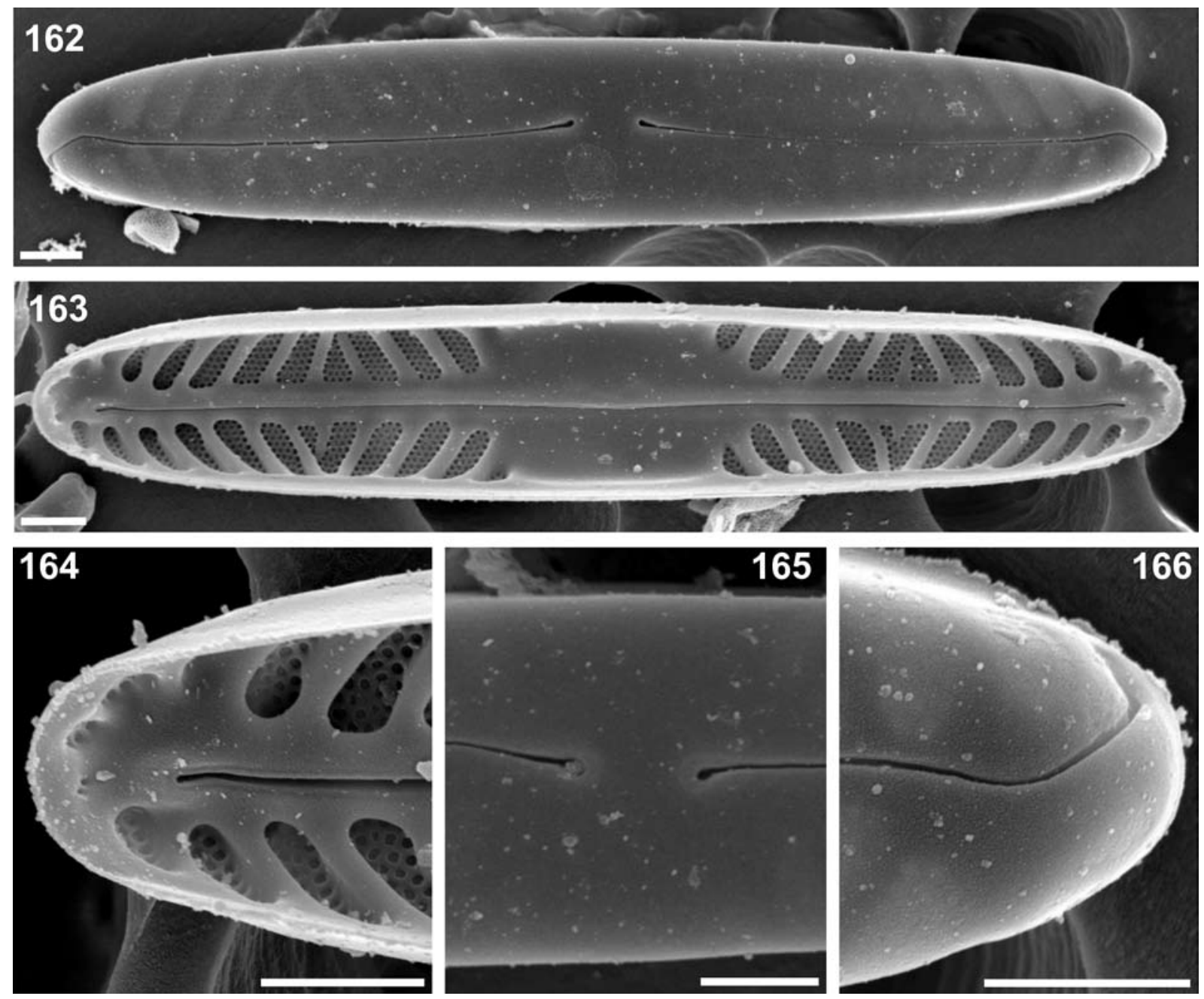

Figs 162-166. Pinnularia acidophila Hofmann et Krammer. Scanning electron micrographs of the type population: (162) external view of the entire valve; (163) internal view of the entire valve; (164) internal view of the apex, showing the raphe termination, the areolae features of the striae and the structure of the alveoli; (165) external view of the raphe in the central area; (166) external view of the apex, showing the distal raphe ending. Scale bars $1 \mu \mathrm{m}$.

The valve apices in P. acidophila are cuneiform and never rounded, and the raphe is filiform and weakly deflected in the middle.

Pinnularia acoricola was described in 1935 by Hustedt. Carter emended the original description in 1972 based on the extremely high variability in shape and size of $P$. acoricola: the valves range from lanceolate to oval with a length varying between 8 to $34 \mu \mathrm{m}$ and a width of 3 to 6 $\mu \mathrm{m}$. The apices are rounded and the stria density varied between 13 and 17 in $10 \mu \mathrm{m}$. Our analyses of the P. acoricola type material (Figs 45-65, 167-172) revealed a range of $10.6-22.9 \mu \mathrm{m}$ in length, 4.3-5.6 $\mu \mathrm{m}$ in width and 14-18 striae in $10 \mu \mathrm{m}$ (Table 4). Nevertheless, P. acoricola differs sufficiently from $P$. aljustrelica by the valve outline.

Pinnularia acoricola has an elliptic- lanceolate valve outline instead of the more lanceolate to narrowly rhombic-lanceolate valves of $P$. aljustrelica furthermore, the valves are wider than those of $P$. aljustrelica.

Pinnularia acoricola var. lanceolata (Fig. 74), a third taxon used for comparison, recently recombined under the name of $P$. acoricolatoba Kulikovskiy, Lange-Bertalot et Metzeltin (KuLIKovskiY et al. 2010), has acutely rounded apices combined with a typical lanceolate valve outline contrary to P. aljustrelica that has broadly rounded apices and a more rhombic-lanceolate outline. Moreover, the central area in P. acoricola var. lanceolata forms a rather elliptically-shaped fascia, a feature never observed in P. aljustrelica. Pinnularia acoricola var. lanceolata valves are larger, wider and have a lower number of striae in $10 \mu \mathrm{m}$ than P. aljustrelica sp. nov. In the type 

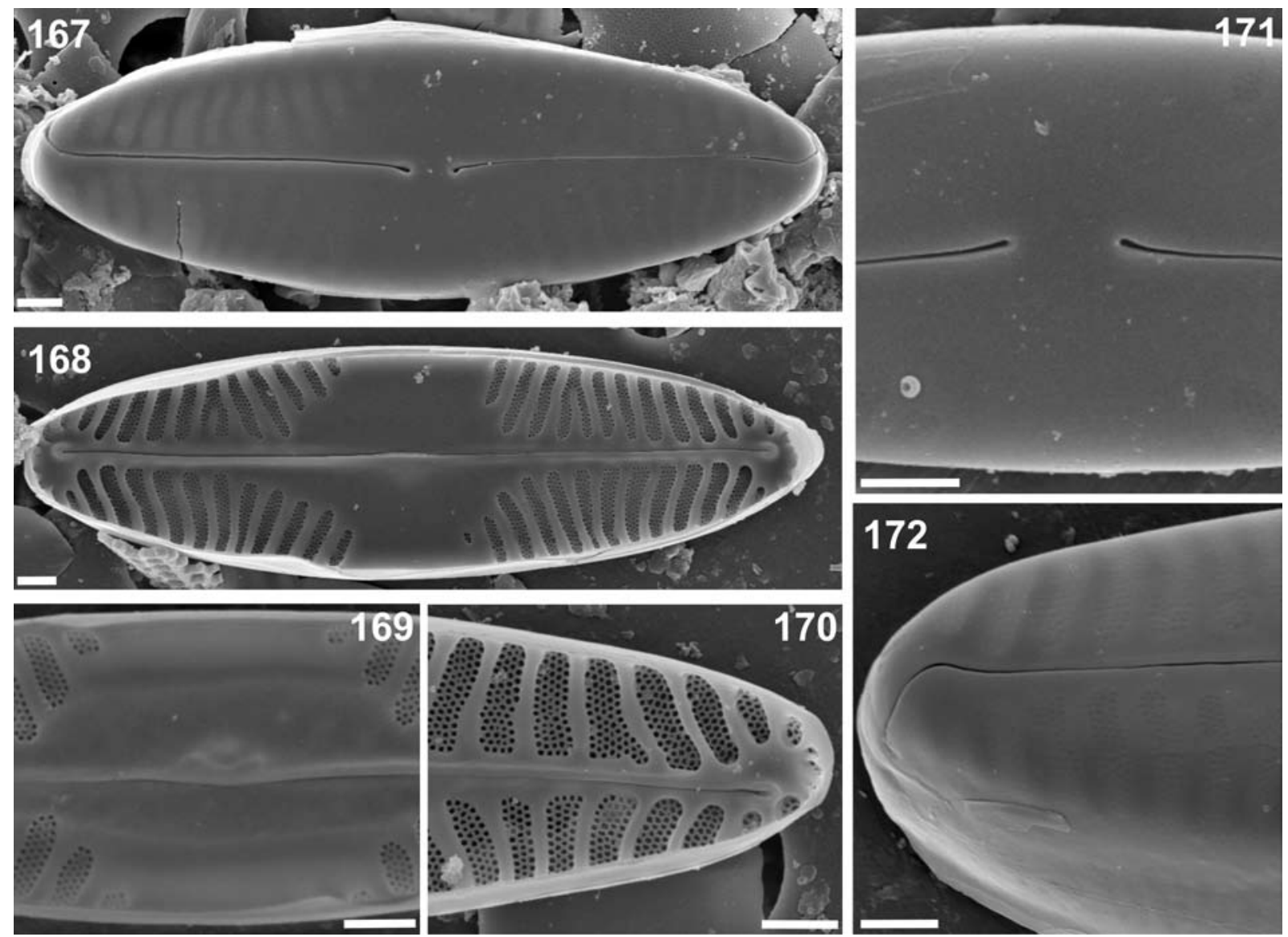

e
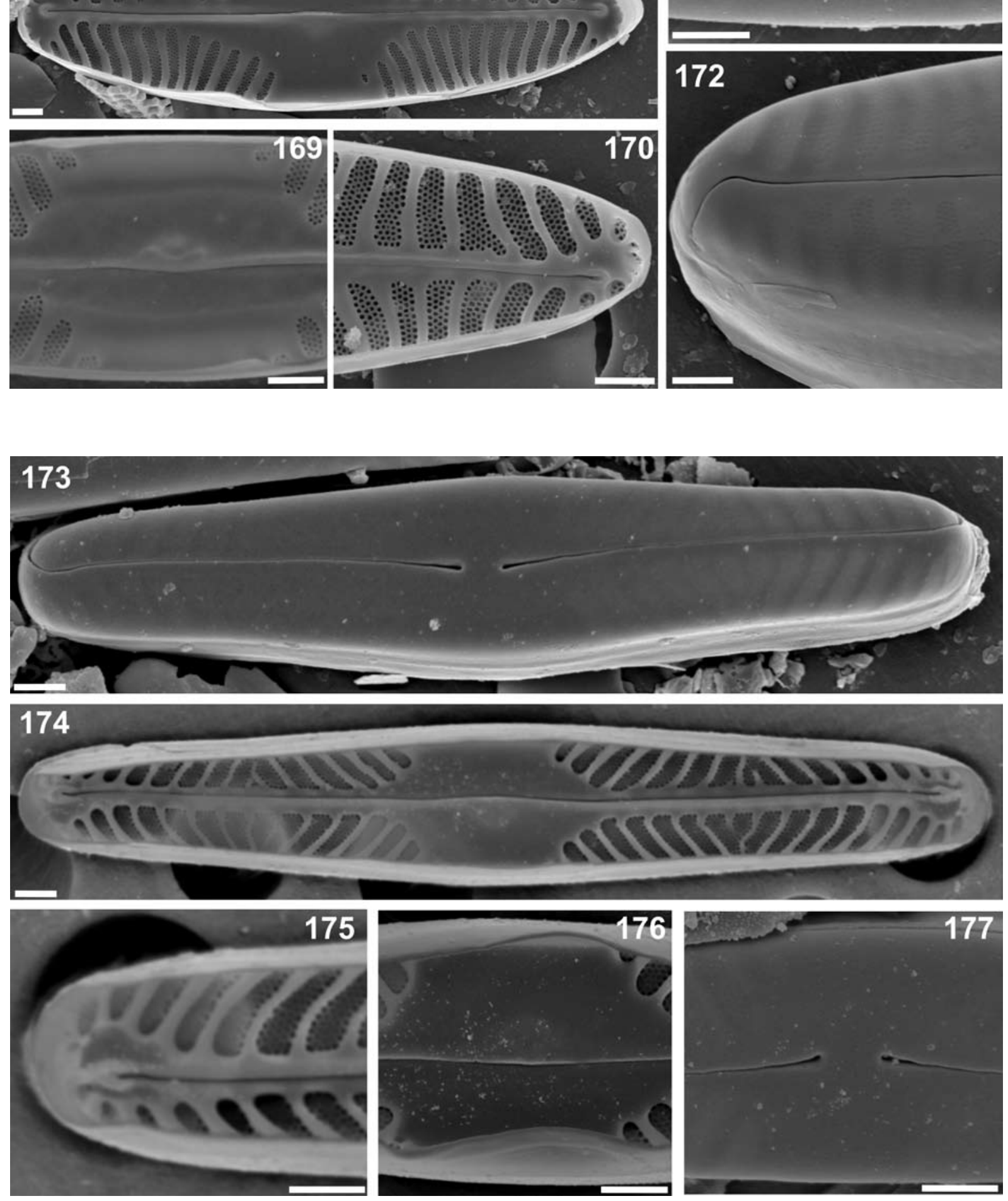
Table 2. Morphometric data of the populations of Pinnularia aljustrelica (Água Forte stream). Minimum, maximum (and medium) values for the most important parameters: length, width and number of striae (total $n=110$ ).

\begin{tabular}{|c|c|c|c|c|c|c|}
\hline Samplings & Spring 2008 & $\begin{array}{l}\text { Summer } \\
2008\end{array}$ & Spring 2009 & Winter 2009 & Spring 2008 & $\begin{array}{l}\text { Total } \\
2008 \\
\& 2009\end{array}$ \\
\hline Sites & $\begin{array}{l}\text { Ponte } \\
\text { Monte } \\
\text { Ruas (type) } \\
(\mathrm{n}=19)\end{array}$ & $\begin{array}{l}\text { Ponte } \\
\text { Monte Ruas } \\
(\mathrm{n}=24)\end{array}$ & $\begin{array}{l}\text { Ponte } \\
\text { Monte Ruas } \\
(\mathrm{n}=18)\end{array}$ & $\begin{array}{l}\text { Ponte } \\
\text { Monte Ruas } \\
(\mathrm{n}=30)\end{array}$ & $\begin{array}{l}\text { Porto de } \\
\text { Beja } \\
(n=19)\end{array}$ & $\begin{array}{l}\text { Ponte } \\
\text { Monte Ruas } \\
- \text { Porto de } \\
\text { Beja } \\
(n=110)\end{array}$ \\
\hline Length $(\mu \mathrm{m})$ & $\begin{array}{l}\text { MIN: } 15.9 \\
\text { MAX: } 24.0 \\
\text { AVG: } 20.7\end{array}$ & $\begin{array}{l}\text { MIN: } 11.3 \\
\text { MAX: } 25.7 \\
\text { AVG: } 19.7\end{array}$ & $\begin{array}{l}\text { MIN: } 14.3 \\
\text { MAX: } 24.3 \\
\text { AVG: } 18.6\end{array}$ & $\begin{array}{l}\text { MIN: } 11.5 \\
\text { MAX: } 20.0 \\
\text { AVG: } 17.4\end{array}$ & $\begin{array}{l}\text { MIN: } 14.5 \\
\text { MAX: } 21.7 \\
\text { AVG } 16.9\end{array}$ & $\begin{array}{l}\text { MIN: } 11.3 \\
\text { MAX: } 25.7 \\
\text { AVG: } 18.7\end{array}$ \\
\hline $\begin{array}{l}\text { Width } \\
(\mu \mathrm{m})\end{array}$ & $\begin{array}{l}\text { MIN: } 3.0 \\
\text { MAX: } 4.1 \\
\text { AVG: } 3.6\end{array}$ & $\begin{array}{l}\text { MIN: } 3.0 \\
\text { MAX: } 3.9 \\
\text { AVG: } 3.6\end{array}$ & $\begin{array}{l}\text { MIN: } 3.0 \\
\text { MAX: } 3.8 \\
\text { AVG: } 3.3\end{array}$ & $\begin{array}{l}\text { MIN: } 3.1 \\
\text { MAX: } 3.7 \\
\text { AVG: } 3.4\end{array}$ & $\begin{array}{l}\text { MIN: } 3.0 \\
\text { MAX: } 3.8 \\
\text { AVG: } 3.3\end{array}$ & $\begin{array}{l}\text { MIN: } 3.0 \\
\text { MAX: } 4.1 \\
\text { AVG: } 3.4\end{array}$ \\
\hline $\begin{array}{l}\text { Number of } \\
\text { striae in } 10 \\
\mu \mathrm{m}\end{array}$ & $\begin{array}{l}\text { MIN: } 15 \\
\text { MAX: } 18 \\
\text { AVG: } 16\end{array}$ & $\begin{array}{l}\text { MIN: } 14 \\
\text { MAX: } 17 \\
\text { AVG: } 15\end{array}$ & $\begin{array}{l}\text { MIN: } 16 \\
\text { MAX: } 18 \\
\text { AVG: } 16\end{array}$ & $\begin{array}{l}\text { MIN: } 15 \\
\text { MAX: } 18 \\
\text { AVG: } 16\end{array}$ & $\begin{array}{l}\text { MIN: } 16 \\
\text { MAX: } 18 \\
\text { AVG: } 17\end{array}$ & $\begin{array}{l}\text { MIN: } 14 \\
\text { MAX: } 18 \\
\text { AVG: } 16\end{array}$ \\
\hline
\end{tabular}

Figs 167-172. Pinnularia acoricola HustedT. Scanning electron micrographs of the type population: (167) external view of the entire valve; (168) internal view of the entire valve; (169) internal view of the raphe in the central area; (170) internal view of the apex, showing the raphe termination, the areolae features of the striae and the structure of the alveoli; (171) external view of the raphe in the central area; (172) external view of the apex, showing the distal raphe ending. Scale bars $1 \mu \mathrm{m}$.

Figs 173-177. Pinnularia aljustrelica Luís, Almeida et Ector. Scanning electron micrographs of the population sampled in Ponte Monte Ruas site in winter 2009, Água Forte stream (Aljustrel, Portugal): (173) external view of the entire valve; (174) internal view of the entire valve; (175) internal view of the apex, showing the raphe termination and the areolae features of the striae; (176) internal view of the raphe in the central area; (177) external view of the raphe in the central area. Scale bars $1 \mu \mathrm{m}$.

slide of P. acoricola var. lanceolata we only found one valve (Fig. 74) that maybe can be identified as $P$. acoricola var. lanceolata, which means that the variety is very rare. Figs $66-73$ represent $P$. acoricola var. acoricola valves found on the type slide of $P$. acoricola var. lanceolata. Fortunately Simonsen (1987, pl. 254, figs 18-21) could illustrate four valves of $P$. acoricola var. lanceolata (Holotype: P1/4, Tobasee, Sumatra, TD4, marked specimens named on the label); this variety differs from the nominate variety of $P$. acoricola by much larger size dimensions, rhombic-lanceolate area and more widely spaced central raphe endings (KuLIKOvsKiY et al. 2010). Several authors (Whitton \& SATAKe 1996; SABATER et al. 2003; Gerhardt et al. 2008; Hobbs et al. 2009; URrea-Clos \& Sabater 2009) reported
P. acoricola as an abundant taxon in AMD affected sites, the species being often reported as a common taxon in acidic environments all over the world: in Java sulphuric streams with $\mathrm{pH}$ of 2.8 to 3.0 (CARTER 1972), in Europe with $\mathrm{pH}$ of 1.5 to 3 (WhitTon \& Diaz 1981) and in New Zealand waters with $\mathrm{pH}$ below 1 (CASSIE \& COOPER 1989). NEgORo (1985) regularly found this species in acidic habitats in Japan, with $\mathrm{pH}$ 2-4 and temperatures of $20.5-46.8^{\circ} \mathrm{C}$. According to Whitton et al. (2000), P. acoricola has been recorded at by far the lowest $\mathrm{pH}$ values for any diatom, with records as low as $\mathrm{pH} 0.2$, though critical studies to confirm viability have not yet been made for the lowest $\mathrm{pH}$ values. WATANABE $\&$ AsAI (1995) reported this taxon also from Japan, in sites having a $\mathrm{pH}$ below 1.1 whereas SABATER 
Table 3. Values of 13 physical and chemical variables and 7 trace metals, for the two sampling sites, in spring and summer of 2008 and spring and winter of 2009 (COD: Chemical Oxygen Demand).

\begin{tabular}{|c|c|c|c|c|c|}
\hline \multirow[t]{2}{*}{ Samplings } & Spring 2008 & Summer 2008 & Spring 2009 & Winter 2009 & Spring 2008 \\
\hline & $\begin{array}{l}\text { Ponte Monte } \\
\text { Ruas (type) }\end{array}$ & $\begin{array}{l}\text { Ponte Monte } \\
\text { Ruas }\end{array}$ & $\begin{array}{l}\text { Ponte Monte } \\
\text { Ruas }\end{array}$ & $\begin{array}{l}\text { Ponte Monte } \\
\text { Ruas }\end{array}$ & Porto de Beja \\
\hline $\mathrm{pH}$ & 1.9 & 2.3 & 2.1 & 2.0 & 2.2 \\
\hline Conductivity $\left(\mu \mathrm{S} . \mathrm{cm}^{-1}\right)$ & 17140 & 14200 & 12200 & 14100 & 12670 \\
\hline Temperature $\left({ }^{\circ} \mathrm{C}\right)$ & 18.5 & 29.2 & 18.6 & 9.1 & 21.0 \\
\hline $\mathrm{NH}_{4}^{+}\left(\mathrm{mg} \cdot \mathrm{l}^{-1}\right)$ & 0 & 0 & 0 & 0 & 0 \\
\hline $\mathrm{NO}_{3}^{-}\left(\mathrm{mg} \cdot 1^{-1}\right)$ & 0 & 295 & 0 & 546 & 0 \\
\hline $\mathrm{PO}_{4}^{3-}\left(\mathrm{mg} \cdot \mathrm{l}^{-1}\right)$ & $<0.02$ & 0.24 & $<0.02$ & 2.00 & $<0.02$ \\
\hline $\operatorname{COD}\left(\mathrm{mg} . \mathrm{l}^{-1}\right)$ & 722 & 657 & 14 & 30 & 166 \\
\hline $\mathrm{Cl}^{-}\left(\mathrm{mg} \cdot \mathrm{l}^{-1}\right)$ & 157 & 184 & 122 & 74 & 144 \\
\hline $\mathrm{SO}_{4}{ }^{2-}\left(\mathrm{mg} . \mathrm{l}^{-1}\right)$ & 28239 & 16995 & 22601 & 36900 & 20169 \\
\hline $\mathrm{Na}^{+}\left(\mathrm{mg} \cdot \mathrm{l}^{-1}\right)$ & 63 & 88 & 47 & 40 & 65 \\
\hline $\mathrm{K}^{+}\left(\mathrm{mg} . \mathrm{l}^{-1}\right)$ & $<5000$ & $<5$ & $<5000$ & 8 & $<5000$ \\
\hline $\mathrm{Mg}^{2+}\left(\mathrm{mg} . \mathrm{l}^{-1}\right)$ & 953 & 438 & 668 & 366 & 652 \\
\hline $\mathrm{Ca}^{2+}\left(\mathrm{mg} .1^{-1}\right)$ & 539 & 250 & 424 & 434 & 375 \\
\hline $\mathrm{Si}^{3+}\left(\mathrm{mg} . \mathrm{l}^{-1}\right)$ & 89 & 45 & 59 & 34 & 83 \\
\hline As $\left(\mathrm{mg} . \mathrm{l}^{-1}\right)$ & 48.50 & 30.00 & 1.90 & 52.17 & 21.70 \\
\hline $\mathrm{Cd}\left(\mathrm{mg} . \mathrm{l}^{-1}\right)$ & 2.48 & 1.70 & 1.80 & 2.10 & 1.62 \\
\hline $\mathrm{Cu}\left(\mathrm{mg} . \mathrm{l}^{-1}\right)$ & 348 & 130 & 265 & 216 & 248 \\
\hline $\mathrm{Fe}\left(\mathrm{mg} . \mathrm{l}^{-1}\right)$ & 6173 & 3688 & 6157 & 4842 & 4543 \\
\hline $\operatorname{Mn}\left(\mathrm{mg} \cdot \mathrm{l}^{-1}\right)$ & 204 & 89 & 117 & 66 & 142 \\
\hline $\mathrm{Pb}\left(\mathrm{mg} . \mathrm{l}^{-1}\right)$ & $<0.01$ & 0.01 & 0.30 & 1.20 & $<0.01$ \\
\hline $\mathrm{Zn}\left(\mathrm{mg} \cdot \mathrm{l}^{-1}\right)$ & 1202 & 970 & 766 & 1112 & 776 \\
\hline
\end{tabular}

et al. (2003) found this taxon in an acid stream in south-western Spain, the Rio Tinto, located in the same geological unit Iberian Pyrite Belt (IPB) as the Aljustrel mining area. JORDAN (2001) also reported that $P$. acoricola was found in acidic waters, with a $\mathrm{pH}$ optimum around 5 , in thermal waters, frequently associated with high iron concentrations. The waters where NeGoro (1944) found the species had high concentrations of aluminium and iron. All Great Britain localities, where this species was found, are typically acidic pounds, that, due to mining activity, have high concentrations of copper, iron and zinc (J.R. CARTER, pers. comm.). It is highly likely that this acidobiontic species may not always correspond to $P$. acoricola and might have been confused in the past with other Pinnularia species.

\section{Acknowledgements}

The authors are grateful to the Biology and Geosciences Departments of the University of Aveiro, Portugal, to the Fundação para a Ciência e Tecnologia, Portugal (grant number SFRH/BD/36137/2007) and to the Public Research Centre - Gabriel Lippmann, Luxembourg for their financial support during this study. We thank the Geosciences Department for assistance in the transport and chemical analyses, the Biology Department and the Public Research Centre - Gabriel Lippmann, Luxembourg for providing support for the diatom study. We would like to express our gratitude to Mrs. Friedel Hinz (Friedrich Hustedt Diatom Collection, Alfred Wegener Institute for Polar and Marine Research) for valuable help with Hustedt's samples and the references used for the preparation of the manuscript, to Dr. Gabriele Hofmann for providing the type material of Pinnularia acidophila. Thanks also to Olatz Aizpurua and Dr. Daša Hlúbiková (Public Research Centre - 
Gabriel Lippmann, Luxembourg) for valuable advice and to Dr. Eduardo A. Morales (Universidad Católica Boliviana San Pablo, Cochabamba, Bolivia) for his suggestions and critical reading of the manuscript.

Table 4. Morphometric data of the type populations of Pinnularia aljustrelica, P. acidophila and P. acoricola. Minimum, maximum (and medium) values for the most important parameters: length, width and number of striae.

\begin{tabular}{|c|c|c|c|}
\hline $\begin{array}{l}\text { Type } \\
\text { material }\end{array}$ & $\begin{array}{l}\text { Pinnularia } \\
\text { aljustrelica } \\
\text { LUís, AlMEIDA } \\
\text { et ECTOR }\end{array}$ & $\begin{array}{l}\text { Pinnularia } \\
\text { acidophila } \\
\text { HOFMANN et } \\
\text { KRAMMER }\end{array}$ & $\begin{array}{l}\text { Pinnularia } \\
\text { acoricola } \\
\text { HusteDT }\end{array}$ \\
\hline $\mathrm{n}$ & 19 & 23 & 28 \\
\hline $\begin{array}{l}\text { Length } \\
(\mu \mathrm{m})\end{array}$ & $\begin{array}{l}\text { MIN: } 15.9 \\
\text { MAX: } 24.0 \\
\text { AVG: } 20.7\end{array}$ & $\begin{array}{l}\text { MIN: } 13.6 \\
\text { MAX: } 17.3 \\
\text { AVG } 15.5\end{array}$ & $\begin{array}{l}\text { MIN: } 10.6 \\
\text { MAX: } 22.9 \\
\text { AVG: } 16.2\end{array}$ \\
\hline $\begin{array}{l}\text { Width } \\
(\mu \mathrm{m})\end{array}$ & $\begin{array}{l}\text { MIN: } 3.0 \\
\text { MAX: } 4.1 \\
\text { AVG: } 3.6\end{array}$ & $\begin{array}{l}\text { MIN: } 2.5 \\
\text { MAX: } 3.1 \\
\text { AVG: } 2.8\end{array}$ & $\begin{array}{l}\text { MIN: } 4.3 \\
\text { MAX: } 5.6 \\
\text { AVG } 4.8\end{array}$ \\
\hline $\begin{array}{l}\text { Number of } \\
\text { striae in } 10 \\
\mu \mathrm{m}\end{array}$ & $\begin{array}{l}\text { MIN: } 15 \\
\text { MAX: } 18 \\
\text { AVG: } 16\end{array}$ & $\begin{array}{l}\text { MIN: } 15 \\
\text { MAX: } 18 \\
\text { AVG: } 17\end{array}$ & $\begin{array}{l}\text { MIN: } 14 \\
\text { MAX: } 18 \\
\text { AVG: } 16\end{array}$ \\
\hline
\end{tabular}

\section{References}

ASTM (1984): Annual Book of ASTM Standards. Water Environmental Technology, vol. 11.01. Pennsylvania: American Society for Testing and Materials.

BAHLS, L.L. (1993): Periphyton bioassessment methods for Montana streams. Water Quality Bureau, Helena, Montana.

Blinn, D. \& Herbst, D. (2003): Use of diatoms and soft algae as indicators of environmental determinants in the Lahontan Basin, USA. Annual Report for California State Water Resources Board Contract Agreement 704558.01.CT766. $-25+10$ pp., USA.

German Chemists Association (1981): Preservation of water samples. Report by the working party on stabilization of samples from the hydrochemistry team of the German Chemists Association. Water Research 15: 233-241.

CArter, J. (1972): Some observations on the diatom Pinnularia acoricola Hustedt. - Microscopy, The Journal of the Quekett Microscopical Club 32: $162-165$.

CAssie, V.\& CoOper, R.C. (1989):Algae of New Zealand thermal areas. - Bibliotheca Phycologica 78: $1-159$.

DeNicola, D.M. (2000): A review of diatoms found in highly acidic environments. - Hydrobiologia 433: $111-122$.

EPA-Environmental Protection Agency (1982): Handbook for Sampling and SamplePreservation of Water and Wastewater (EPA/600/4-82/029). United States Environmental Protection Agency. - 402 pp., Cincinnati.

ESRI (2008): ArcGIS 9.3. Redlands, California, USA. Environmental Science Research Institute 1999-2008.

Fukushima, H.; Yoshitake, S. \& Ko-Bayashi, T. (2002): Three new diatoms Pinnularia from acid waters in Japan. - Diatom 18: 1-12.

Gerhardt, A.; Janssens de Bisthoven, L.; Guhr, K.; Soares, A.M.V.M. \& Pereira, M.J. (2008): Phytoassessment of acid mine drainage: Lemna gibba bioassay and diatom community structure. - Ecotoxicology 17: 47-58.

Hargreaves, J.W.; Lloyd, E.J.H. \& Whitton, B.A. (1975): Chemistry and vegetation of highly acidic streams. - Freshwater Biology 5: 564576.

Hobbs, W.O.; Wolfe, A.P.; Inskeer, W.P.; AmsKold, L. \& Konhauser, K.O. (2009): Epipelic diatoms from an extreme acid environment: Beowulf Spring, Yellowstone National Park, U.S.A. Nova Hedwigia, Beiheft 135: 71-83.

Hustedt, F. (1935): Die fossile Diatomeenflora in den Ablagerungen des Tobasees auf Sumatra. Tropische Binnengewässer, Band VI. - Archiv für Hydrobiologie, Supplement 14: 143-192.

Idei, M. \& Mayama, S. (2001): Pinnularia acidojaponica M. IDEI et H. KoBAyAsI sp. nov. and $P$. valdetolerans MAYAMA et $\mathrm{H}$. KoBAYAsi sp. nov. - new diatom taxa from Japanese extreme environments. - In: JAHN, R.; KocIOLEK, J.P.; Witkowski, A. \& Compère, P. (eds): LangeBertalot-Festschrift. Studies on Diatoms. Dedicated to Prof. Dr. Dr. h.c. Horst LangeBertalot on the Occasion of his $65^{\text {th }}$ Birthday. - pp. 265-278, A.R.G. Gantner Verlag K.G., Ruggell.

JoRDAN, R.W. (2001): Taxonomy, morphology and distribution of two Pinnularia species from acidic lakes and rivers in Yamagata and Miyagi Prefectures, Northeast Japan. - In: JAHN, R.; Kociolek, J.P.; Witkowski, A. \& Compère, P. (eds): Lange-Bertalot-Festschrift. Studies on Diatoms. Dedicated to Prof. Dr. Dr. h.c. Horst Lange-Bertalot on the Occasion of his $65^{\text {th }}$ Birthday. - pp. 279-302, A.R.G. Gantner Verlag K.G., Ruggell.

Krammer, K. (2000): The genus Pinnularia. - In: Lange-Bertalot, H. (ed.): Diatoms of Europe. Diatoms of the European Inland waters and comparable habitats. Vol. 1. - 703 pp., A.R.G. Gantner Verlag, K.G., Ruggell.

Kulikovskiy, M.; Lange-Bertalot, H. \& Metzeltin, 
D. (2010): Specific rank for several infraspecific taxa in the genus Pinnularia EHRENB. - Algologia 20: $357-367$.

Lessmann, D.; Deneke, R.; Ender, R.; Hemm, M.; Kapfner, M.; Krumbeck, H.; Wollmann, K. \& Nixdorf, B. (1999): Lake Plessa 107 (Lusatia, Germany) - an extremely acidic shallow mining lake. - Hydrobiologia 408/409: 293-299.

Luís, A.T.; Teixeira, P.; Almeida, S.F.P.; Ector, L.; Matos, J.X. \& Ferreira dA Silva, E.A. (2009): Impact of acid mine drainage (AMD) on water quality, stream sediments and periphytic diatom communities in the surrounding streams of Aljustrel mining area (Portugal). - Water, Air, and Soil Pollution 200: 147-167.

Metzeltin, D.; Lange-Bertalot, H. \& GarcíaRoDRíGUEZ, F. (2005): Diatoms of Uruguay compared with other taxa from South America and elsewhere. - In: LANGE-Bertalot, H. (ed.): Iconographia Diatomologica. Annotated Diatom Micrographs. Taxonomy-BiogeographyDiversity. Vol. 15. - 736 pp., A.R.G. Gantner Verlag K.G., Ruggell.

Negoro, K. (1944): Untersuchungen über die Vegetation der mineralogen-azidotrophen Gewässer Japans. - Science Reports of the Tokyo Bunrika Daigaku, Section B, 6: 231-374.

Negoro, K. (1985): Diatom flora of the mineralogenous acidotrophic inland waters of Japan. - Diatom 1: $1-8$.

Round, F.E.; Crawford, R.M. \& Mann, D.G. (1990): The Diatoms. Biology \& Morphology of the Genera. - 747 pp., Cambridge University Press, Cambridge.

Sabater, S.; Buchaca, T.; Cambra, J.; Catalan, J.; Guasch, H.; Ivorra, N.; Muñoz, I.; Navarro, E.; Real, M. \& Romaní, A. (2003): Structure and function of benthic algal communities in an extremely acid river. - Journal of Phycology 39: 481-489.

Schmidt, A.; Schmidt, M.; Fricke, F.; Heiden, H.; Müller, O. \& Hustedt, F. (1934): Atlas der Diatomaceen-kunde. Series VIII. - pp. 97-98, pls 385-392, O.R. Reisland, Leipzig.

Simonsen, R. (1987): Atlas and Catalogue of the Diatom Types of Friedrich Hustedt. 3 vols. - J. Cramer, Berlin \& Stuttgart.

Skousen, J.; Sextone, A.; Garbutt, K. \& Sencindiver, J. (1994): Acid mine drainage treatment with wetlands and anoxic limestone drains. - In: Kent, D. (ed.): Applied Wetland Science and Technology. - pp. 263-282, Lewis Boca Raton, FL, USA.

Stevenson, R.J. \& PAN, Y. (1999): Assessing environmental conditions in rivers and streams with diatoms. - In: STOermer, E.F. \& SMOL, J.P. (eds): The Diatoms: Applications for the Environmental and Earth Sciences. - pp. 11-40,
Cambridge University Press, Cambridge.

Urrea-Clos, G. \& Sabater, S. (2009): Comparative study of algal communities in acid and alkaline waters from Tinto, Odiel and Piedras river basins (SW Spain). - Limnetica 29: 261-272.

Van de Vijver, B.; Frenot, Y. \& Beyens, L. (2002): Freshwater diatoms from Ile de la Possession (Crozet Archipelago, Subantarctica). Bibliotheca Diatomologica 46: 1-412.

Watanabe, T. \& Asai, K. (1995): Pinnularia acoricola HuSTEDT var. acoricola as an environmental frontier species occurred in inorganic acid waters with 1.1 2.0 in $\mathrm{pH}$ value. - Diatom 10: 9-11.

Whitton, B.A.; Albertano, P. \& Satake, K. (2000): Introduction. - In: Whitton, B.A., Albertano, P. \& SATAKe, K. (eds): Chemistry and Ecology of Highly Acidic Environments. - Hydrobiologia 433: 1-2.

Whitton, B.A. \& DiAz, B.M. (1981): Influence of environmental factors on photosynthetic species composition in highly acidic waters. Verhandlungen der Internationalen Vereinigung für Theoretische und Angewandte Limnologie 21: 1459-1465.

Whitton, B.A. \& Satake, K. (1996): Phototrophs in highly acidic waters: an overview. - In: SATAKE, K. (ed.): Proceedings of the International Symposium on Acidic Deposition and its Impacts, 10-12 December 1996, Tsukuba, Japan. - pp. 204-211, Center for Global Environmental Research, National Institute for Environmental Studies of the Environment Agency of Japan, Tsukuba, Japan.

WydrzycKa, U. \& LANGE-Bertalot, H. (2001): Las diatomeas (Bacillariophyceae) acidófilas del río Agrio y sitios vinculados con su cuenca, volcán Poás, Costa Rica. - Brenesia 55-56: 1-68.

(C) Czech Phycological Society (2012)

Received February 2, 2011

Accepted June 6, 2011 